\title{
Diagnostic Accuracy of the 2002 EULAR Criteria for the Clinical Suspicion of Rheumatoid Arthritis and the Sensitivity of the New 2010 ACR/EULAR Classification Criteria in "Early Arthritis"
}

\author{
2002 EULAR Klinik Romatoid Artrit Şüphesi Kriterlerinin Tanısal Doğruluğu ve \\ Yeni 2010 ACR/EULAR Sinıflandırma Kriterlerinin “Erken Artrit”teki Duyarlılığı
}

Lyudmila SIZOVA

Orenburg State Medical Academy, Orenburg, Russian Federation

\begin{abstract}
Objectives: In this study we investigated the diagnostic and prognostic significance of the 2002 European League Against Rheumatism (EULAR) criteria for the clinical suspicion of rheumatoid arthritis (RA) and the sensitivity of the new 2010 American College of Rheumatology (ACR)/EULAR classification criteria for RA in patients with "early arthritis".

Patients and methods: The subjects were 250 outpatients (211 females, 39 males; mean age $46.1 \pm 11.8$ years; range 19 to 73 years) with "early arthritis". The mean disease duration was $4.9 \pm 3.3$ months. The criteria of inclusion of patients in the study were: (i) patients aged 18 years and older, (ii) clinical suspicion of RA according to EULAR (2002) criteria or persistent arthritis/arthralgia ( $>6$ weeks), (iii) duration of disease $<1$ year, and (iv) written consent of the patient to participate in the study. The exclusion criteria were: (i) presence of a definite diagnosis of other rheumatic diseases before the onset of the study, and (ii) refusal of the patient to participate in the study. The diagnostic significance of the criteria was determined by the sensitivity and specificity. Predictive significance was estimated on positive and negative predictive values. The diagnostic effectiveness was also considered.
\end{abstract}

Results: The 2002 EULAR criteria had higher diagnostic accuracy in identifying all three criteria in the patients. The negative predictive values ranging from $87.84 \%$ to $98.0 \%$ indicate that the absence of one of these criteria, especially arthritis of three or more joints, reduces the probability of RA diagnosis and requires investigation for other possible diseases with involvement of the joints. Two criteria was found to have the highest sensitivity among the 2010 ACR/EULAR classification criteria for RA: (i) the presence of synovitis in at least one joint, and (ii) symptom duration $\geq 6$ weeks. "Definite" RA could be identified in $98(86 \%)$ patients according to new criteria (a score of $\geq 6 / 10$ ) at the beginning of the study.

Conclusion: The obtained data indicates the feasibility of using the 2002 EULAR criteria for screening patients with early RA and the usefulness of the new 2010 ACR/EULAR classification criteria for identification patients with "definite RA" and initiation of therapy with disease-modifying antirheumatic drugs.

Key words: Accuracy; classification criteria; diagnostic significance; early rheumatoid arthritis; predictive significance.
Amaç: Bu çalışmada 2002 EULAR (European League Against Rheumatism) klinik romatoid artrit (RA) şüphesi kriterlerinin tanısal ve prognostik önemi ve yeni 2010 ACR (American College of Rheumatology)/EULAR RA sınıflandırma kriterlerinin "erken artrit"li hastalardaki duyarlılığı araştırıldı.

Hastalar ve yöntemler: Denekler, "erken artrit"li 250 ayakta tedavi hastasını (211 kadın, 39 erkek; ort. yaş $46.1 \pm 11.8$ yıl; dağılım 19-73 yıl) içermekteydi. Ortalama hastalık süresi $4.9 \pm 3.3$ ay idi. Hastaların çalışmaya dahil edilme kriterleri şu şekildeydi: (i) hastanın 18 yaş ve üstünde olması, (ii) EULAR (2002) kriterlerine göre klinik RA şüphesi ya da persistan artrit/artralji varlığı ( $>6$ hafta süreli), (iii) hastalık süresinin $<1$ yıl olması ve (iv) hastanın çalışmaya katılmak için yazılı onay vermesi. Hastaların çalışmaya alınmama kriterleri şunlardı: (i) çalışmanın başlangıç tarihinden önce başka romatizmal hastalıkların bulunduğuna dair kesin tanı varlığı ve (ii) hastanın araştırmaya katılmayı reddetmesi. Kriterlerin tanısal önemi, duyarlılığa ve özgüllüğe göre belirlendi. Öngörüsel önem, pozitif ve negatif öngörüsel değerlere göre hesaplandı. Tanısal etkinlik de hesaba katılı.

Bulgular: 2002 EULAR kriterlerinin, hastalardaki üç kriterin tamamını tanımlamada daha yüksek tanısal doğruluğa sahip olduğu gözlemlendi. Yüzde 87.84 ile \%98.0 arasında değişen negatif öngörü değerleri, özellikle üç ya da daha fazla eklemde artrit bulunması olmak üzere, bu kriterlerden birinin mevcut olmamasının, RA tanısı olasılığını azalttığını ve eklem tutulumuyla seyreden diğer olası hastalıkların araştırılmasını gerektirdiğini göstermektedir. 2010 ACR/EULAR romatoid artrit sınıflandırma kriterleri arasında iki kriterin en yüksek duyarlılığa sahip olduğu saptandı: (i) en az bir eklemde sinovit varlığı ve (ii) $\geq 6$ haftalık semptom süresi. Çalışmanın başlangıcında yeni kriterlere göre ( $\geq 6 / 10$ puan) 98 hastada ( $86 \%$ ) "kesin" RA saptanabildi.

Sonuç: Elde edilen veriler, erken RA'ı hasta taraması için 2002 EULAR kriterlerinin kullanımasının uygunluğunu ve yeni 2010 ACR/EULAR sınıflandırma kriterlerinin "kesin RA"lı hastaların tespiti ve hastalık modifiye edici antiromatizmal ilaç tedavisine başlanması açısından faydasını ortaya koymaktadır.

Anahtar sözcükler: Doğruluk; sınıflandırma kriterleri; tanısal önem; erken romatoid artrit; öngörüsel önem.

Received: July 13, 2010 Accepted: October 11, 2010

Correspondence: Lyudmila Sizova, M.D. Orenburg State Medical Academy, Chair of Polyclinic Therapy, Orenburg, Russian Federation.

Tel: +7 3532755055 e-mail: lusizova@mail.ru

(อ2011 Turkish League Against Rheumatism. All rights reserved. 
Rheumatoid arthritis (RA) is a chronic systemic inflammatory disease that affects about $1 \%$ of the population..$^{[1-3]}$ Over the long course of the disease, the clinical picture is usually very clear and with the aid of the 1987 classification criteria of the American College of Rheumatology (ACR), it can be diagnosed with high confidence. However, in the early stage of the disease, diagnosis is a real challenge. The ACR criteria are unsuitable for early diagnosis because the clinical symptoms at onset of the disease are often nonspecific.

The early diagnosis of rheumatoid arthritis has become a high priority in recent years due to the availability of effective, disease-modifying antirheumatic drugs and biologics which not only improve patients' well-being but also influence the eventual outcome in terms of joint destruction. ${ }^{[4-6]}$

Emery et al. ${ }^{[5]}$ recommended the diagnostic algorithm "Clinical suspicion of RA" which included three criteria for a well-founded suspicion of RA in the early stage: (i) the presence of three or more swollen joints, (ii) tenderness of metacarpo- or metatarsophalangeal joints revealed by "squeeze" test of the hand or foot, and (iii) presence of morning stiffness of at least 30 minutes. ${ }^{[5]}$ They were adopted as criteria by the European League Against Rheumatism (EULAR) for suspicion of RA in 2002, ${ }^{[7]}$ but the diagnostic and prognostic significance of these criteria in "early arthritis" have yet to be investigated. Moreover, although ACR/EULAR classification criteria for RA (2010) to identify persons at earlier stages of the disease were developed recently for intervention with disease-modifying antirheumatic drugs (DMARDs), ${ }^{[8]}$ the sensitivity of the new criteria needs to be tested.

To investigate the diagnostic and prognostic significance of the 2002 EULAR criteria for clinical suspicion of rheumatoid arthritis (RA) and the sensitivity of the new 2010 ACR/EULAR classification criteria for RA in patients with "early arthritis".

\section{PATIENTS AND METHODS}

The research was carried out at the Chair of Polyclinic Therapy in Orenburg State Medical Academy. The criteria of inclusion of patients in the study were: (i) age 18 years or older, (ii) clinical suspicion of RA by EULAR (2002) criteria or persistent arthritis/arthralgia (more than 6 weeks), (iii) duration of disease for less than one year, and (iv) written approval of the patient to participate in the study. The exclusion criteria were: (i) presence of definite diagnosis of other rheumatic disease before the onset of the study, and (ii) patient disclaimer to participate in research.

The subjects were 250 outpatients (211 females, 39 males; mean age $46.1 \pm 11.8$ years; range 19 to 73 years) with "early arthritis". The mean disease duration was $4.9 \pm 3.3$ months.

Common clinical and laboratory examinations were carried out for all patients. Determination of C-reactive protein (CRP) and rheumatoid factor (RF) in the serum of all patients was performed by the qualitative test of latex-agglutination. If patients consented to further study on the blood markers of $\mathrm{RA}$, they were sent to the laboratory to determine the quantitative content in serum of their concentrations of total RF ( $\mathrm{n}=26 ; 22.8 \%)$ using the immunoturbidimetric method (normal values $0-14 \mathrm{IU} / \mathrm{ml}$ ) or IgM-RF $(\mathrm{n}=63$; $55.3 \%)$ anti-citrullinated protein antibodies (ACPA) $(\mathrm{n}=41 ; 36 \%)$ and antibodies to modified citrullinized vimentin (MCVA) $(n=45 ; 39.5 \%)$ in serum through the enzyme-linked immunosorbent assay (ELISA) (normal level $<20 \mathrm{IU} / \mathrm{ml}$ ). Standard X-rays of the hand or foot in front projection were performed in all patients. Ultrasonography of radiocarpal, metacarpophalangeal and knee joints was performed using the "Diasonics Ultrasound" (Diasonics Ultrasound, San Jose, CA, USA) in B-mode. Other tests (search for infectious agents, determination of uric acid level, etc.) were used to rule out the diagnosis of other diseases (non-RA).

After taking results of the preliminary survey and initial examinations into account, patients with "early arthritis" were assigned to one of three groups: (i) early RA-58 (23.2\%) patients, including four (1.6\% of all patients) with probable RA, (ii) non-RA (other diagnosis)-83 (33.2\%) patients: 55 (22\%) cases of osteoarthritis, $23(9.2 \%)$ cases of reactive arthritis, four (1.6\%) cases of psoriatic arthropathy and one (0.4\%) case of gout, and (iii) unspecified arthritis (UA)-109 (43.6\%) patients. The clinical characteristics of patients are summarized in table 1 . From the table it can be seen that women prevailed among patients with "early arthritis" in all three groups $(\mathrm{p}<0.001)$. The mean age of patients with early RA exceeded the mean ages of patients with other diagnoses and UA $(p<0.05)$. The mean duration of an articulate syndrome was comparable for all three groups.

During the two-year observation of patients with a diagnosis of UA, RA was identified in 56 patients. As a result, of the 250 patients with "early arthritis" at the start of the study the diagnosis of RA was confirmed in $114(45.6 \%)$ patients. Assessment of the 


\begin{tabular}{|c|c|c|c|c|c|c|}
\hline \multirow[t]{2}{*}{ Parameters } & \multicolumn{2}{|c|}{ Patients with early RA $(n=58)$} & \multicolumn{2}{|c|}{ Patients with non-RA $(\mathrm{n}=83)$} & \multicolumn{2}{|c|}{ Patients with UA $(n=109)$} \\
\hline & $\mathrm{n}$ & $\%$ & $\mathrm{n}$ & $\%$ & $\mathrm{n}$ & $\%$ \\
\hline \multicolumn{7}{|l|}{ Gender } \\
\hline Male & 3 & 5.2 & 14 & 16.9 & 22 & 20.2 \\
\hline Female & 55 & $94.8^{*}$ & 69 & $83.1^{*}$ & 87 & $79.8^{*}$ \\
\hline $\begin{array}{l}\text { Mean age, } \\
\text { years Me (Q1-Q3) }\end{array}$ & \multicolumn{2}{|c|}{$51(48-57)$} & \multicolumn{2}{|c|}{$50(41-54)^{\#}$} & \multicolumn{2}{|c|}{$45(32-51)^{\# \$}$} \\
\hline $\begin{array}{l}\text { Duration articular syndrome, } \\
\text { months } \mathrm{Me}(\mathrm{Q} 1-\mathrm{Q} 3)\end{array}$ & \multicolumn{2}{|c|}{$4.63(2.3-8.0)$} & \multicolumn{2}{|c|}{$5(2-7)$} & \multicolumn{2}{|c|}{$4(2-6.5)$} \\
\hline
\end{tabular}

2010 ACR/EULAR classification criteria for RA was performed in this group with the use of parameters that were identified at the moment of recruitment into the clinical trial. The scoring system was based on the presence of synovitis in at least one joint, absence of an alternative diagnosis that explained the synovitis better, and achievement of a total score of six or greater (of a possible 10) from the individual scores in four domains: number and site of involved joints (score range 0-5), serologic abnormality (score range 0-3), elevated acute-phase response (score range 0-1) and symptom duration (2 levels; range $0-1){ }^{[8]}$ Hence, the cut-off point for "definite RA" was set at $\geq 6 / 10$.

Statistical analysis was performed using the software package "Statistica 6.0" (StatSoft, Inc., USA, 2001). The statistical hypothesis about the normality of distribution was tested for all quantitative parameters. The arithmetic mean $(\mathrm{M})$ and standard deviation (SD) were calculated to describe the parameters with a normal distribution. If conditions of normality of distribution were not fulfilled, the median $(\mathrm{Me})$ and interquartile range between the first and third quartiles (Q1-Q3) were determined. The nonparametric Mann-Whitney U-test was used for comparison of the two groups.
The Chi-square test was applied to compare distributions of criteria in groups. Differences between the parameters were considered statistically significant at a value of $\mathrm{p}<0.05$.

The diagnostic significance of clinical parameters was determined by the sensitivity (the probability of a positive outcome in patients with the presence of the desired sign) and specificity (probability of negative results in patients who do not have this sign). Predictive significance was estimated on positive predictive value (the probability of the unknown disease on a roll positive result) and negative predictive value (the probability of a the absence of pathology negative result). Diagnostic efficiency of the criterion was calculated in terms of the percentage of the true (both positive and negative) test results in relation to the total number of results (Table 2).

\section{RESULTS}

Analysis of the detection frequency of clinical suspicion criteria of RA proposed by EULAR (2002) in 250 patients with "early arthritis" at the start of the study showed that $102(40.8 \%)$ patients had all three criteria,

Table 2. Characteristics of diagnostic tests

\begin{tabular}{|c|c|c|}
\hline & \multicolumn{2}{|c|}{ Disease } \\
\hline & $\begin{array}{l}\text { Patients with early } \\
\text { rheumatoid arthritis }\end{array}$ & $\begin{array}{l}\text { Patients with non } \\
\text { rheumatoid arthritis }\end{array}$ \\
\hline \multicolumn{3}{|l|}{ Index test/symptom } \\
\hline \multirow[t]{2}{*}{ Positive results } & a & $\mathrm{b}$ \\
\hline & True positive result & False positive result \\
\hline \multirow[t]{2}{*}{ Negative results } & c & $\mathrm{d}$ \\
\hline & False negative result & True negative result \\
\hline \multicolumn{3}{|c|}{ Diagnostic sensitivity $=a /(a+c) \times 100 \%$} \\
\hline \multicolumn{3}{|c|}{ Diagnostic specificity $=d /(b+d) \times 100 \%$} \\
\hline \multicolumn{3}{|c|}{ Positive predictive value $=\mathrm{a} /(\mathrm{a}+\mathrm{b}) \times 100 \%$} \\
\hline \multicolumn{3}{|c|}{ Negative predictive value $=d /(c+d) \times 100 \%$} \\
\hline \multicolumn{3}{|c|}{ Diagnostic effectiveness (accuracy) $=a+d /(a+b+c+d) \times 100 \%$} \\
\hline
\end{tabular}


Table 3. Detection frequency of the separate EULAR criteria of clinical suspicion of rheumatoid arthritis in patients with "early arthritis" ( $\mathrm{n}=250)$

\begin{tabular}{|c|c|c|c|c|c|c|}
\hline \multirow[t]{2}{*}{$\begin{array}{l}\text { EULAR criteria of } \\
\text { clinical suspicion of RA }\end{array}$} & \multicolumn{2}{|c|}{$\begin{array}{l}\text { Patients } \\
\text { with early RA }(\mathrm{n}=58)\end{array}$} & \multicolumn{2}{|c|}{$\begin{array}{c}\text { Patients } \\
\text { with non-RA ( } \mathrm{n}=83)\end{array}$} & \multicolumn{2}{|c|}{$\begin{array}{c}\text { Patients } \\
\text { with UA }(n=109)\end{array}$} \\
\hline & $\mathrm{n}$ & $\%$ & $\mathrm{n}$ & $\%$ & $\mathrm{n}$ & $\%$ \\
\hline Arthritis of three or more joints & 57 & 98.3 & 33 & $39.8^{*}$ & 65 & $59.6^{*}$ \\
\hline Positive 'squeeze' test of the foot or hand & 55 & 94.8 & 50 & $60.2^{*}$ & 77 & $70.6^{* *}$ \\
\hline Morning stiffness $\geq 30$ minutes & 51 & 87.9 & 25 & $30.1^{*}$ & 61 & $56.0^{*}$ \\
\hline All three criteria & 49 & 84.5 & 18 & $21.7^{\star}$ & 35 & $32.1^{*}$ \\
\hline
\end{tabular}

EULAR: European League Against Rheumatism; RA: Rheumatoid arthritis; UA: unspecified arthritis; Statistical significance of differences in values compared with a group of early RA (chi-square test); ${ }^{*}$ p $<0.0001 ;{ }^{* *}: \mathrm{p}<0.0005$.

60 (24\%) had two criteria, 50 (20\%) had one criterion, and $38(15.2 \%)$ patients were without a single criterion, but had persistent arthritis/arthralgia for at least six weeks.

Of the 102 patients who met all three EULAR criteria, the diagnosis of RA at the first examination was established for $49(48.0 \%)$ patients with other diagnoses made in 18 (17.7\%) patients and UA in 35 (34.3\%) patients. Even the presence of all three criteria of early RA in $1 / 3$ of patients in the third group did not allow verification of the diagnosis at the first visit.

The evaluation of the detection frequency of the separate criteria in each group of patients with "early arthritis" is presented in table 3 . Table 3 shows that the combination of all three EULAR criteria were detected in the group with early RA most frequently compared with the non-RA (other diagnoses) and UA groups $(\mathrm{p}<0.001)$.

The data from groups of patients with early RA and non-RA was used to evaluate the diagnostic and prognostic significance of clinical suspicion criteria of RA (Table 4).

The results of the sensitivity assessment of the 2010 ACR/EULAR classification criteria for RA in 114 patients with confirmed RA diagnosis during two years of observation are shown in table 5 . The highest sensitivity among the 2010 ACR/EULAR classification criteria for RA was revealed for two criteria, namely the presence of synovitis in at least one joint, and symptom duration $\geq 6$ weeks. A total of 98 (86\%) patients had the score $\geq 6 / 10$ indicating the presence of "definite RA" while the score in $16(14 \%)$ patients was $<6 / 10$. However, one of these patients had radiographic evidence of RA (juxta-articular osteoporosis). Furthermore, arthritis became seropositive within six months in two of these patients and after six months in two other patients. Finally, 13 patients had erosion of the metacarpal bones that were found on ultrasonography of the metacarpophalangeal joints that allowed classifying them as having RA.

\section{DISCUSSION}

Table 4 shows that the EULAR criteria had high sensitivity for the early diagnosis of RA (84.5-98.3\%). The specificity of the criteria varied from $39.8 \%$ to $69.9 \%$ in the identification of separate criteria and increased to $78.3 \%$ in the case of detection of all three criteria. The composite "squeeze" test is a useful technique for the clinical evaluation of a group of small, adjacent joints such as the metacarpophalangeal and metatarsophalangeal joints. ${ }^{[9]}$ But as our study showed, the specificity of this test was lower than arthritis of three or more joints and morning stiffness

Table 4. Diagnostic and prognostic significance of the EULAR criteria (2002) for early diagnostics of rheumatoid arthritis

\begin{tabular}{lccccc}
\hline $\begin{array}{l}\text { EULAR criteria of } \\
\text { clinical suspicion of RA }\end{array}$ & $\begin{array}{c}\text { Sensitivity } \\
\%\end{array}$ & $\begin{array}{c}\text { Specificity } \\
\%\end{array}$ & $\begin{array}{c}\text { Positive predictive } \\
\text { value, } \%\end{array}$ & $\begin{array}{c}\text { Negative predictive } \\
\text { value, } \%\end{array}$ & $\begin{array}{c}\text { Diagnostic effectiveness } \\
\text { (accuracy), \% }\end{array}$ \\
\hline $\begin{array}{l}\text { Arthritis of three or more joints } \\
\text { Positive "squeeze" test }\end{array}$ & 98.3 & 60.2 & 63.3 & 98.0 & 75.9 \\
$\quad$ of the foot or hand & 94.8 & 39.8 & 52.4 & 91.7 & 62.4 \\
Morning stiffness $\geq 30$ minutes & 87.9 & 69.9 & 67.1 & 89.2 & 77.3 \\
All three criteria & 84.5 & 78.3 & 73.1 & 87.8 & 80.9 \\
\hline EULAR: European League Against Rheumatism; RA: Rheumatoid arthritis. & & & \\
\hline
\end{tabular}




\begin{tabular}{|c|c|c|}
\hline \multirow[t]{2}{*}{ Classification criteria for RA } & \multicolumn{2}{|c|}{ Patients with RA $(n=114)$} \\
\hline & $\mathrm{n}$ & $\%$ \\
\hline \multicolumn{3}{|l|}{ A. Joint involvement\# } \\
\hline 1 large joint & - & - \\
\hline 2-10 large joints & 4 & 3.5 \\
\hline 1-3 small joints (with or without involvement of large joints) & 17 & 14.9 \\
\hline 4-10 (with or without involvement of large joints) & 14 & 12.3 \\
\hline$>10$ joints (at least one small joint) & 79 & 69.3 \\
\hline Total & & 100.0 \\
\hline \multicolumn{3}{|l|}{ B. Serology (at least one test result is needed for classification) } \\
\hline Negative RF and negative ACPA $\dagger \dagger$ & 51 & 44.7 \\
\hline Low RF or low ACPA & 29 & 25.4 \\
\hline High RF or high ACPA & 34 & 29.8 \\
\hline \multicolumn{3}{|l|}{$\begin{array}{l}\text { C. Acute-phase reactants (at least one test result is needed for } \\
\text { classification) }\end{array}$} \\
\hline Normal CRP and normal ESR & 30 & 26.3 \\
\hline Abnormal CRP or abnormal ESR & 84 & 73.7 \\
\hline \multicolumn{3}{|l|}{ D. Duration of symptoms } \\
\hline$<6$ weeks & 8 & 7.0 \\
\hline$\geq 6$ weeks & 106 & 93.0 \\
\hline \multicolumn{3}{|c|}{$\begin{array}{l}\text { ACR: American College of Rheumatology; EULAR: European League Against Rheumatism; RA: Rheumatoid arthritis; ACPA: } \\
\text { Anti-citrullinated protein antibodies; ESR: Erythrocyte sedimentation rate; CRP: C-reactive protein; \#: "Large joints" were } \\
\text { shoulders, elbows, hips, knees, and ankles. "Small joints" were the metacarpophalangeal joints, proximal interphalangeal joints, } \\
\text { second through fifth metatarsophalangeal joints, thumb interphalangeal joints, and wrists. Joint involvement to any swollen or } \\
\text { tender joint on examination was confirmed by ultrasonography of synovitis. Distal interphalangeal joints, first carpometacarpal } \\
\text { joints, and first metatarsophalangeal joints were excluded from assessment. } \dagger \text { : Negative RF or ACPA that were less than or equal } \\
\text { to the upper limit of normal (ULN) for the assay; low-positive values were higher than the ULN but } \leq 3 \text { times the ULN for the assay; } \\
\text { high-positive were }>\text { times the ULN for the assay. Where rheumatoid factor (RF) information was only available as positive or } \\
\text { negative (latex-test), a positive result was scored as low-positive for RF. }\end{array}$} \\
\hline
\end{tabular}

$\geq 30$ minutes. The positive predictive value of EULAR criteria for early RA also had higher rates (73.1\%) in identifying all three criteria in patients. The accuracy of the 2002 EULAR criteria reached $80.9 \%$ if the patients had all three criteria. The negative predictive values ranging from $87.84 \%$ to $98.0 \%$ indicate that the absence of one of these criteria, especially arthritis of three or more joints, reduces the probability of the diagnosis of RA and demands a search or an exception of other possible diseases with involvement of the joints.

Most patients (86\%) in whom a diagnosis of RA was later established already had "definite RA" at the beginning of the study according to the new 2010 ACR/ EULAR classification criteria for RA. Although 14\% of patients had scores $<6 / 10$, they fulfilled the criteria cumulatively over time or had erosive arthritis typical of RA as the basis for recognizing them as having RA. The difference between the new 2010 ACR/EULAR and the 1987 ACR classification criteria consists in the exclusion of morning stiffness, involvement of not less than three joints, radiological changes and rheumatoid nodules. These signs are often absent in the first year of illness. Fundamentally new is the quantitative assessment of serologic markers.
However, despite available data in the literature on the high specificity of AMCV, they are not yet included in the criteria. Whether these antibodies are an alternative to the ACPA is an interesting question for future discussion.

In conclusion, the obtained data indicates the feasibility of using the 2002 EULAR criteria for the screening of patients with early RA. The simultaneous identification of all three criteria is optimal for the prediction of RA in patients with "early arthritis" because it raises the diagnostic accuracy of criteria to $80.9 \%$. The new 2010 ACR/EULAR classification criteria can be useful for the identification of patients with "definite RA" and the initiation of therapy with DMARDs.

\section{Declaration of conflicting interests}

The author declared no conflicts of interest with respect to the authorship and/or publication of this article.

\section{Funding}

The author received no grant support for the research and authorship of this article. 


\section{REFERENCES}

1. Lee DM, Weinblatt ME. Rheumatoid arthritis. Lancet 2001;358:903-11.

2. Strand V. Recent advances in the treatment of rheumatoid arthritis. Clin Cornerstone 1999;2:38-50.

3. Suresh E. Diagnosis of early rheumatoid arthritis: what the non-specialist needs to know. J R Soc Med 2004;97:421-4.

4. Cush JJ. Early rheumatoid arthritis-is there a window of opportunity? J Rheumatol Suppl 2007;80:1-7.

5. Emery P, Breedveld FC, Dougados M, Kalden JR, Schiff $\mathrm{MH}$, Smolen JS. Early referral recommendation for newly diagnosed rheumatoid arthritis: evidence based development of a clinical guide. Ann Rheum Dis 2002; 61:290-7.

6. Rubbert-Roth A, Finckh A. Treatment options in patients with rheumatoid arthritis failing initial TNF inhibitor therapy: a critical review. Arthritis Res Ther 2009;11 Suppl 1:S1.

7. Karateev DE, Luchikhina EL, Tiurina LN, Chemeris NA, Pogozheva EIu, Lukina GV, et al. Early diagnosis of rheumatoid arthritis in modern clinical practice (results of a follow-up of a Moscow cohort of early arthritis patients participating in the program RADICAL). Ter Arkh 2008;80:8-13.

8. Aletaha D, Neogi T, Silman AJ, Funovits J, Felson DT, Bingham CO 3rd, et al. 2010 rheumatoid arthritis classification criteria: an American College of Rheumatology/European League Against Rheumatism collaborative initiative. Ann Rheum Dis 2010;69:1580-8.

9. Visser H, Le Cessie S, Vos K, Breedveld FC, Hazes JMW. How to diagnosis rheumatoid arthritis (RA) early: the development of diagnostic criteria. Arthritis Rheum 2000;43(Suppl 9):S154. 